\title{
Relative growth of Acantholobulus schmitti (Rathbun, 1930) (Crustacea, Brachyura, Panopeidae) at Guaratuba Bay, southern Brazil
}

\author{
Frigotto, SF. ${ }^{*}$, Marochi, MZ. and Masunari, S. \\ Postgraduate Program on Zoology, Department of Zoology, Federal University of Paraná, Centro Politécnico, \\ Jardim das Américas, Caixa Postal 19020, CEP 81531-980 Curitiba, Paraná, Brazil \\ "e-mail:frigotto@hotmail.com murilomz2@hotmail.com
}

Received August 9, 2012 - Accepted October 26, 2012 - Distributed November 29, 2013

(With 2 figures)

\begin{abstract}
A study on the relative growth of the crab Acantholobulus schmitti (Rathbun, 1930) (Decapoda, Brachyura, Panopeidae) was performed with allometric techniques. The species is associated with lanterns used for oyster farming at Guaratuba Bay, southern Brazil. Crabs were obtained from five lanterns from March through December 2009. The following morphological characteristics were measured: the carapace width $(\mathrm{CW})$, the height and length of the major cheliped propodus (LPH and LPL), the width of the female abdomen at the base of the $4^{\text {th }}$ somite (AW) and the length of the male gonopod (GL). A total of 1,004 individuals of $A$. schmitti were measured, of which 451 were males, 323 non-ovigerous females and 230 ovigerous females. The $\mathrm{CW}$ of the males varied from 1.87 to $11.86 \mathrm{~mm}$, that of non-ovigerous females from 1.44 to $8.77 \mathrm{~mm}$ and that of ovigerous females from 4.09 to $11.12 \mathrm{~mm}$. The plot of LPH against CW showed a mean inflection point at $3.67 \mathrm{~mm} \mathrm{CW}$ for the males. This result indicated that male crabs are juvenile below this value and adult above it. For the females, the corresponding inflection point occurred at $3.36 \mathrm{~mm} \mathrm{CW}$ in the plot of AW against CW. These results, CW x LPH and CW x AW, highlight the importance of chelae enlargement at the onset of maturation in males. Similarly, the widening of the abdomen in females is required to accommodate egg clutches during the reproductive period. Heterochely was recorded in both sexes. Right-handed crabs were more frequent than left-handed ones, with percentages of $75.8 \%$ in males and $82.7 \%$ in females. The population of $A$. schmitti from Guaratuba Bay becomes sexually mature at an earlier age than $A$. schmitti from the coast of São Paulo state. The lanterns used in oyster farming furnish a safe habitat in which these crabs can spend their entire benthic life.
\end{abstract}

Keywords: morphometry, allometry, heterochely, crab, oyster lantern.

\section{Crescimento relativo de Acantholobulus schmitti (Rathbun, 1930) (Crustacea, Brachyura, Panopeidae) na Baía de Guaratuba, sul do Brasil}

\section{Resumo}

Um estudo sobre o crescimento relativo do caranguejo Acantholobulus schmitti (Rathbun, 1930) (Decapoda Brachyura Panopeidae) foi realizado utilizando o método alométrico. A espécie está associada às lanternas de ostras na Baía de Guaratuba, no sul do Brasil. Os caranguejos foram obtidos de cinco lanternas de março a dezembro/2009. Foram obtidas as seguintes dimensões somáticas dos caranguejos: largura da carapaça $(\mathrm{CW})$, altura e comprimento do própodo do maior quelípodo (LPH e LPL), largura do abdômen da fêmea na base do quarto somito (AW) e o comprimento de gonópodo dos machos (GL). Um total de 1.004 indivíduos de A. schmitti foi medido, destes 451 foram machos, 323 fêmeas e 230 fêmeas ovígeras. $\mathrm{O} \mathrm{CW}$ dos machos variou de 1,87 a 11,86 mm, enquanto para fêmeas não-ovígeras de 1,44 a 8,77 mm e fêmeas ovígeras de 4,09 a 11,12 mm. O gráfico de dispersão dos pontos empíricos entre CW e LPH mostrou um ponto de inflexão em 3,67 mm CW dentre os machos, indicando que abaixo deste valor, os caranguejos machos ainda são juvenis e acima dele, adultos. Para fêmeas, este ponto foi estabelecido em 3,36 mm CW no gráfico de dispersão entre CW e AW. Esses resultados das relações CW x LPH e CW x AW, destacam a importância do alargamento da quela no início da maturação dos machos, enquanto o alargamento do abdômen é uma demanda natural para as fêmeas, a fim de acomodar ovos no período reprodutivo. A heteroquelia ocorreu em ambos os sexos, sendo caranguejos destros mais frequentes do que os canhotos: $75,8 \%$ dentre os machos e $82,7 \%$ dentre as fêmeas. A população de $A$. schmitti da Baía de Guaratuba torna-se sexualmente madura mais cedo do que no litoral de São Paulo, e as lanternas de ostreicultura constituem um habitat seguro para estes caranguejos viverem plenamente a sua vida bentônica.

Palavras-chave: morfometria, alometria, heteroquelia, caranguejo, lanterna de ostras. 


\section{Introduction}

Natural oyster reefs can support a wide diversity of organisms, including algae, sessile and vagile invertebrates, fish and birds, which may occur at lower densities in unconsolidated sediment habitats (Ruesink et al., 2005). Likewise, oyster farming can provide an additional or alternative habitat for native epifauna (Marenghi et al., 2010).

Certain xanthid crabs can be important predators of shellfish, but there is very little information about this relationship. Members of this family have been recorded regularly in farm cultures of the oyster Crassostrea virginica (Gmelin, 1791) on the east coast of North America (Wells, 1961). The occurrence of oyster and mussel shells in the digestive tract of the crab Panopeus herbstii H. Milne Edwards, 1834 has been described (Milke and Kennedy, 2001). These observations indicate that decapods can play an important role in controlling the population growth of gastropods, bivalves and barnacles on oyster banks (Silliman et al., 2004).

The panopeid crab Acantholobulus schmitti (Rathbun, 1930) occurs widely along the western Atlantic coast from Suriname to Argentina, including the Brazilian coast from Ceará to Santa Catarina State (Swennen et al., 1982; Williams and Boschi, 1990; Melo, 1996). Most studies on A. schmitti are taxonomic (Sankarankutty and Manning, 1997; Felder and Martin, 2003), despite its wide geographical distribution. The species is abundant in the lanterns used for oyster farming in the Guaratuba Bay estuary, Paraná state, southern Brazil, where the species occurs at an average density of up to 130 crabs per lantern (Frigotto, 2011).

Different body parts can grow at different rates. As a result, adults and juveniles can differ morphologically. This phenomenon is known as relative growth or allometric growth (Hartnoll, 1978) and it can be used to distinguish immature from mature crabs in a population, as well as to demonstrate differences in the growth patterns of the body parts of males and females (FernándezVergaz et al., 2000; McLay and Brink, 2009).

Studies on relative growth are facilitated in crustaceans because the rigid exoskeleton of these organisms allows precise measurements. Additionally, certain body parts associated with sex and puberty show strong contrasts in shape. These contrasts make crustaceans very attractive for studies of relative growth (Hartnoll, 1978, 1982; Castiglioni and Negreiros-Fransozo, 2004; Alves et al., 2005; Masunari and Dissenha, 2005; Masunari et al., 2005; Pinheiro and Taddei, 2005; Biagi and Mantelato, 2006; Gerhart and Bert, 2008; Araújo et al., 2012; Castiglioni and Coelho, 2011).

Heterochely (differences in size, shape and function between the right and left chelipeds) varies considerably among crustaceans. Although it occurs in both sexes, it is more common or more accentuated in males because they usually use the chelipeds for agonistic purposes (Hartnoll, 1982; Finney and Abel, 1981; Muino et al., 1999; Garvey and Stein, 1993; Pinheiro and Fransozo,
1993; Grandjean et al., 1997; Mariappan et al., 2000; Trevisan and Santos, 2012).

The purpose of this study is to determine the carapace size at which males and females of the crab A. schmitti attain their sexual maturity. The analysis was based on an investigation of relative growth. Heterochely in this species was also analyzed.

\section{Material and Methods}

Crabs were obtained from the Sítio Sambaqui marine farm, located in the estuary of Pinheiros River, Guara-

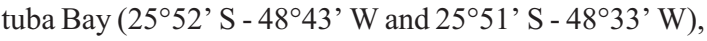
municipality of Guaratuba, Paraná state, Brazil. Sampling was conducted from March through December 2009.

Collections of the vagile macrofauna associated with oyster cultivation were made from five lantern nets maintained without management (i.e., without cleaning procedures) for one to nine months. Each lantern was wrapped in a nylon net bag (70 cm long, $80 \mathrm{~cm}$ diameter and $0.60 \mathrm{~mm}$ mesh size) before it was released from the long line. The set was then transported by boat to the marine farm facility. The crabs were manually captured. In the laboratory, the animals were sorted, fixed in $4 \%$ formaldehyde, and preserved in $70 \%$ alcohol. The crabs were identified based on Melo (1996). Individuals of Acantholobulus schmitti were sexed, and the following measurements were obtained: the carapace width $(\mathrm{CW})$, the height and length of the major cheliped propodus (LPH and LPL, respectively), the abdominal width of the females at the base of the $4^{\text {th }}$ somite (AW) and the gonopod length (GL) of the males (see Figure 1). Small individuals (under $3.00 \mathrm{~mm} \mathrm{CW}$ ) were measured with the aid of a digital microscope Dino-Lite Pro AM413 (AnMo Electronics Corporation, Hsinchu, Taiwan; www.dinolite.com) with 1.3 mega pixels resolution. Individuals above $3.00 \mathrm{~mm} \mathrm{CW}$ were measured with a digital caliper (accuracy $0.01 \mathrm{~mm}$ ).

The relative growth of $A$. schmitti was described with the power equation $\mathrm{Y}=\mathrm{aX} \mathrm{X}^{\mathrm{b}}$. The equation was log-transformed to linear form $(\log y=\log a+b \log X)$. The CW was used as an independent variable and other body dimensions as dependent variables (Huxley, 1950). After an initial analysis of the measurement data, REGRANS software (Pezzuto, 1993) was used to determine the mean value of the inflection point joining the relative growth curve of the juveniles with that of the adults. The presence of such inflection point theoretically indicates the size of the onset of sexual maturity in Decapoda (based on measurements of the major cheliped and the abdomen and for males and females, respectively) (Hartnoll, 1974, 1978).

The values of "a" and " $b$ " are the intercept of the straight-line growth curve and the constant of allometry, respectively. The value $b=1$ indicates isometric growth, $\mathrm{b}>1$ positive allometric growth and $\mathrm{b}<1$ negative allometric growth. To analyze the patterns of growth in terms of allometry or isometry, a Student t-test with a significance level of 5\% was used (Huber, 1985). 

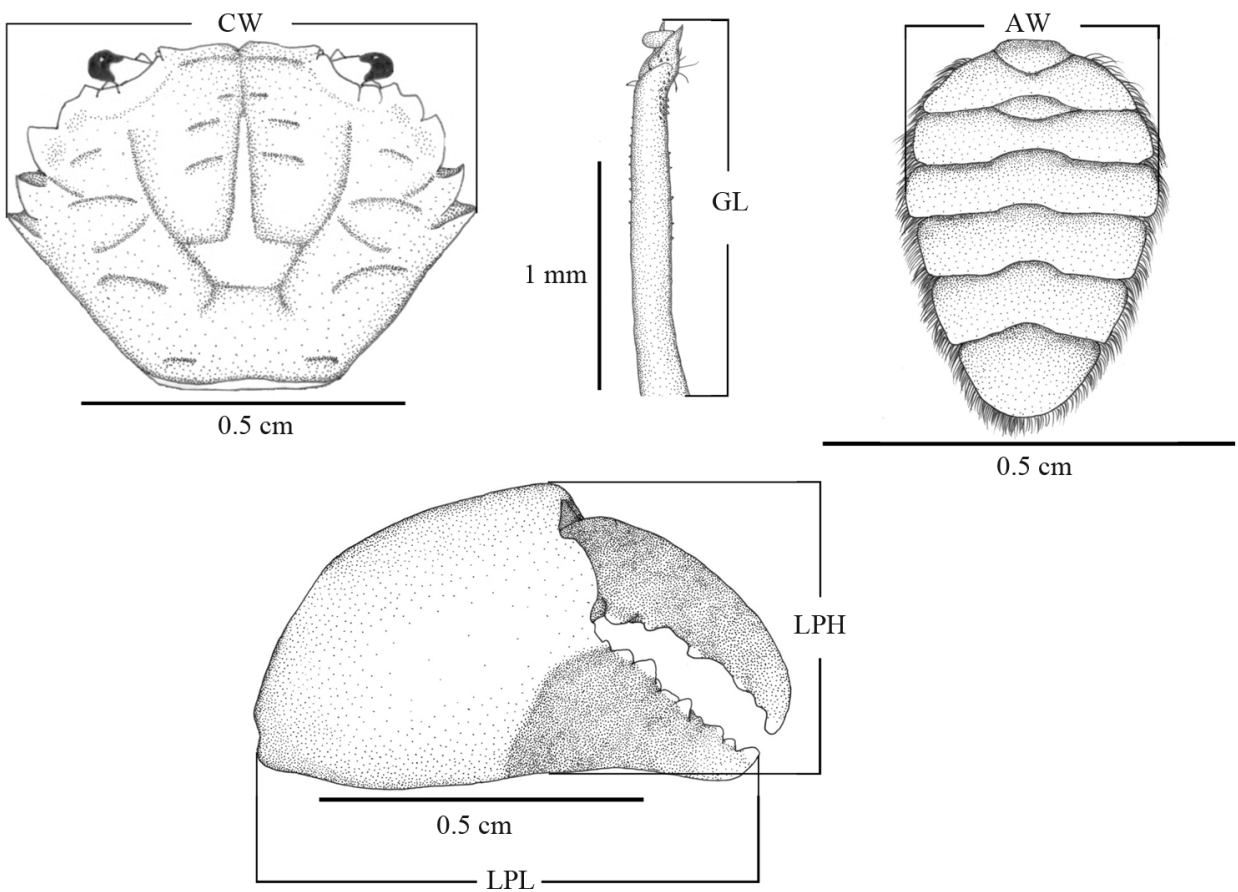

Figure 1 - Acantholobulus schmitti. Schematic drawings showing the morphometric measures used in this study (adapted from Marochi and Masunari, 2011). CW = carapace width; AW = abdomen width; GL = gonopod length; $\mathrm{LPH}=$ propodus height of the major cheliped; LPL = propodus length of the major cheliped.

To evaluate the possible statistical differences between the growth lines of juveniles and adults for males and females, the intercepts and slopes of the lines were analysed with an analysis of covariance (ANCOVA) based on a 95\% confidence interval (Sokal and Rohlf, 1979).

Differences in the average carapace width were assessed with a Mann-Whitney test. The mean length and height of the right and left propodus of males and females and the difference in propodus measurements between sexes were evaluated with an ANOVA. The relationship between the length and height of the propodus among same-sexed animals and between males and females was tested with an ANCOVA.

The number of individuals measured was not equal for all morphometric correlations because lost or damaged appendages or segments occurred in several crabs.

\section{Results}

A total of 1,004 specimens of Acantholobulus schmitti were measured, of which 451 were males, 323 non-ovigerous females and 230 ovigerous females. The $\mathrm{CW}$ of the males ranged from 1.87 to $11.86 \mathrm{~mm}$, that of the non-ovigerous females from 1.44 to $8.77 \mathrm{~mm}$ and that of the ovigerous females from 4.09 to $11.12 \mathrm{~mm}$. The average $\mathrm{CW}$ of the adult males $(7.06 \pm 1.96 \mathrm{~mm})$ was significantly greater than that of the adult females $(5.95 \pm$ $1.13 \mathrm{~mm}$ ) (Mann-Whitney $\mathrm{U}=7.1971$; $\mathrm{p}<0.05$ ).
The equations, inflection points and coefficients of determination indicating changes during the ontogeny of males and females are shown in Table 1.

The morphometric dimensions associated with relative growth and reproductive maturity were the LPH for males and the AW for females. The other measurements exhibited inflection points that were not associated with the onset of puberty, primarily because the values of these inflection points differed substantially from the size of the smallest ovigerous female found in the samples.

The relationship between CW and LPH had an inflection point at $3.67 \mathrm{~mm} \mathrm{CW}$. This result implies that crabs with a CW less than this value are still sexually immature (i.e., juveniles), whereas those with a CW greater than this value are sexually mature (i.e., adults). For females, the value of the inflection point for the relationship between $\mathrm{CW}$ and $\mathrm{AW}$ was $3.36 \mathrm{~mm} \mathrm{CW}$ (Table 1 and Figure 2).

The straight-line relationships indicating morphological sexual maturity for juveniles and adults showed statistically similar intercepts $(\mathrm{f}=2.8587, \mathrm{p}=0.0876)$ and different slopes $(\mathrm{f}=4.4774, \mathrm{p}=0.0327)$. The corresponding straight-line relationships for juvenile and adult females showed statistically different intercepts $(f=12.76, p=0.0007)$ and similar slopes $(f=0.1082$, $\mathrm{p}=0.7416)$.

The length of the major propodus ranged from 1.92 to $10.67 \mathrm{~mm}$ in males and from 1.69 to $6.37 \mathrm{~mm}$ in females; the height of the major propodus ranged from 0.90 to $6.28 \mathrm{~mm}$ in males and from 0.71 to $4.54 \mathrm{~mm}$ in females. 
Frigotto, SF., Marochi, MZ. and Masunari, S.

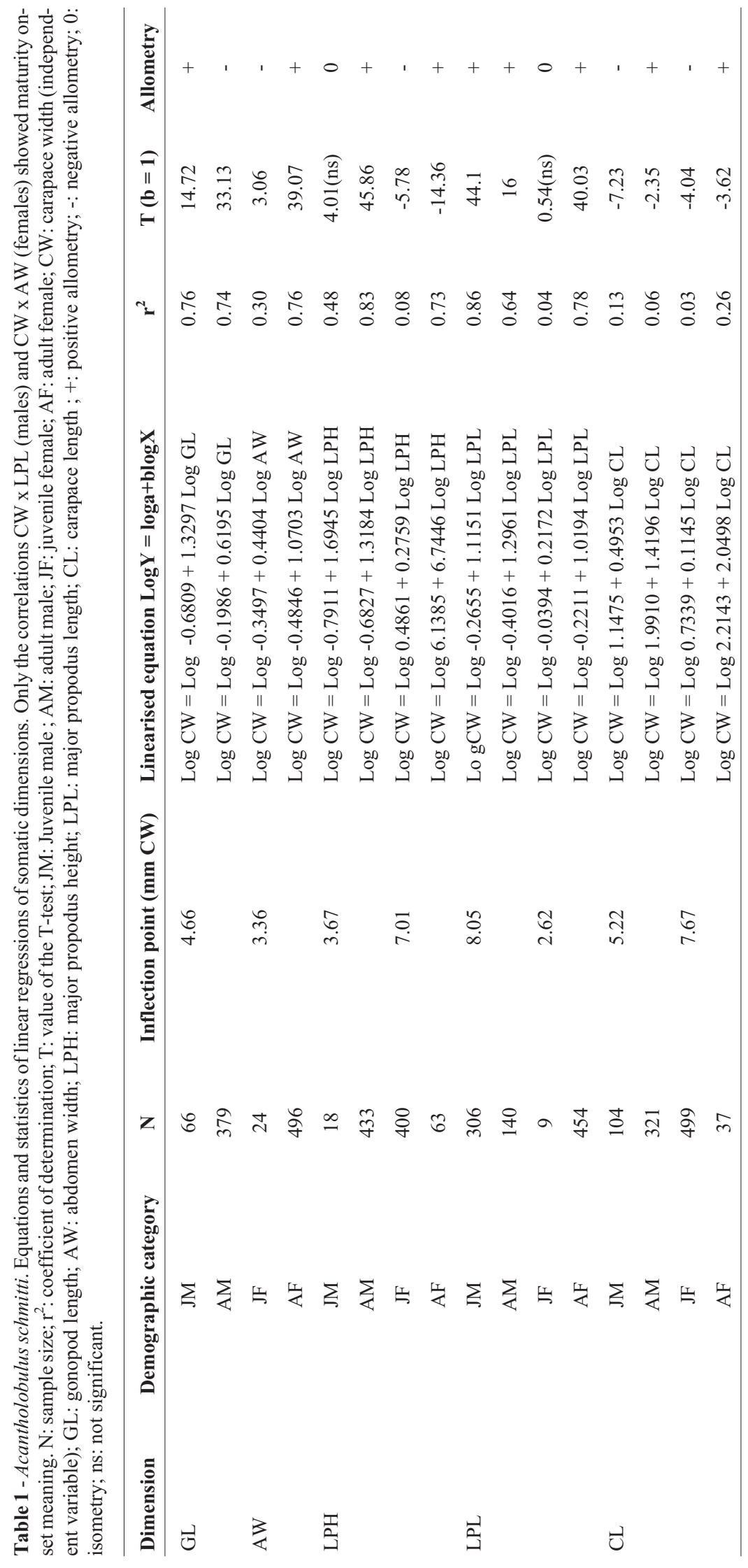



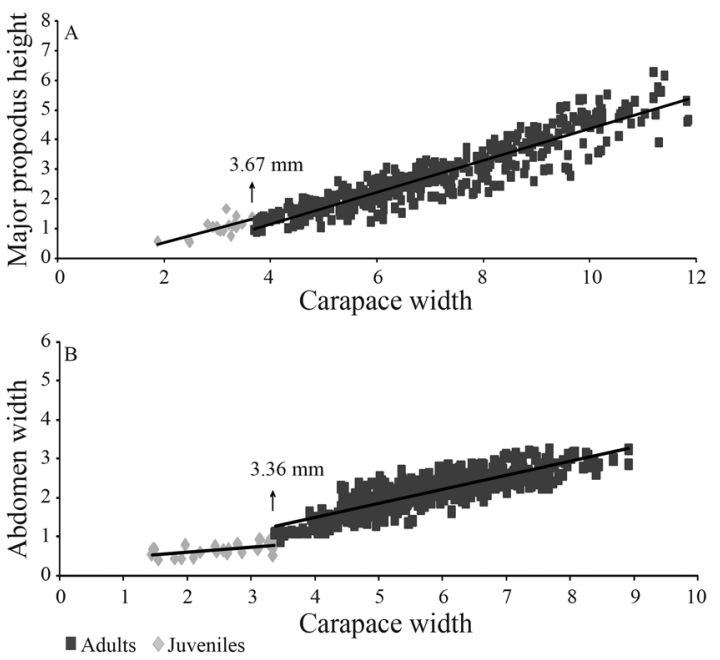

Figure 2 - Acantholobulus schmitti. Comparisons between straight-lines growth curves for juveniles and adults in males and females in the growth charts. A: LPH x CW (males). B: $\mathrm{AW} \times \mathrm{CW}$ (female). The inflection points are indicated in both graphs. The data points at the left (lozenges) correspond to the juveniles (males, $\mathrm{N}=18$; females, $\mathrm{N}=24$ ), and those at the right (squares) to the adults (males, $\mathrm{N}=433$; females, $\mathrm{N}=496$ ). CW: carapace width; LHP: height of the major cheliped propodus; AW: abdomen width.

Heterochely occurred in both sexes. The right cheliped was larger than the left in $75.8 \%$ of the males and $82.7 \%$ of the females. Furthermore, the males had a larger propodus than the females at the same CW $(p<0.0001)$ in both the length and height dimensions.

The relationship between the length and height of the major chelipeds of the males showed different intercepts $(f=66.30, p<0.0001)$ and different slopes $(f=24.39$, $\mathrm{p}<0.0001)$ for juveniles and adults. For the females, this relationship showed a similar slope $(\mathrm{f}=1.87, \mathrm{p}=0.1681)$ but different intercepts $(f=31.31, p<0.0001)$. These results imply that the changes in cheliped size between developmental phases are more abrupt in the males than in the females.

\section{Discussion}

The range of carapace width found in the present study (1.87-11.86 mm for males and 1.44-11.12 mm for females) was greater than that previously reported by Fumis et al. (2007), who obtained values of $2.5-9.8 \mathrm{~mm}$ for males and 2.8-9.4 mm for females for a population of Acantholobulus schmitti inhabiting the Ubatuba region, São Paulo State. Our data suggest that artificial biotopes such as oyster lanterns can harbor entire populations (except planktonic larvae), including adults, ovigerous females and juveniles, providing a suitable biotope for the full development of these crabs.

Furthermore, the inflection points found in the present study $(3.67 \mathrm{~mm} \mathrm{CW}$ for males and $3.36 \mathrm{~mm} \mathrm{CW}$ for females) are slightly lower than those recorded by Fumis et al. (2007): $4.5 \mathrm{~mm} \mathrm{CW}$ for males and $3.5 \mathrm{~mm}$ for females. Although these authors, using a different methodology from that of the present study, calculated the inflection point of the male growth curve based on the gonopod length, it appears that the population from Guaratuba Bay reaches sexual maturity earlier than the population from the São Paulo coast, most likely due to differences in the local environmental conditions. In the current study, the length of the gonopod was not chosen as an indicator of morphological sexual maturity because this structure showed a negative allometry in adult males. In addition, the finding of a CW of $4.09 \mathrm{~mm}$ for the smallest ovigerous female from Guaratuba Bay provides strong evidence that the values of the inflection points calculated with the REGRANS technique are valid indicators of the size of females at the onset of sexual maturity.

The two morphometric dimensions that indicated the beginning of morphological sexual maturity (LPH for males and AW for females) in the present study are common developmental landmarks in panopeid crabs (Table 2). The LPH has positive allometric growth in all species in juveniles, in adults or in both of these stages. However, isometry and negative allometry are also recorded for this character. These findings indicate that relative growth is influenced by local climatic conditions (Masunari and Dissenha, 2005; Masunari, 2006). Similarly, the AW shows positive allometric growth in both juvenile and adult stages for all species, with the exception of $A$. schmitti in the present study. This exception could be a result of the substantial difference in sample size between adult females $(\mathrm{N}=496)$ and juveniles $(\mathrm{N}=24)$.

Although the relative growth of the LPL did not yield an inflection point value that indicated the onset of sexual maturity in males in the present study, this dimension followed the same positive allometry as the LPH. This tendency is also evident in other panopeid species (Table 2).

An enlarged female abdomen is associated with a larger volume of the incubatory space and the potential capacity to hold a large egg mass (Leme, 2006). In contrast, the abrupt growth of the major cheliped in males indicates a possible need to fight with other males to ensure reproductive success (Hartnoll, 1974). This assumption has been generally accepted for many other brachyuran species (Guerrero-Ocampo et. al., 1998; Masunari and Swiech-Ayoub, 2003; Masunari et al., 2005; Castiglioni et al., 2006; Araújo et al., 2012).

The GL shows positive allometric growth only in the juvenile stage of most panopeid species (Table 2); the adults show negative or isometric growth. The pattern found in this paper for A. schmitti indicates that the gonopod grows at a greater rate during the juvenile phase than in the adult phase. This growth rate can be explained by a reproductive strategy in which the species exhibits further development of the gonopod in the juvenile phase so that the structure will be fully functional after the transition to adulthood. 
Frigotto, SF., Marochi, MZ. and Masunari, S.

Table 2 - Slope values of the straight lines $(=b)$ in the scatter plots between the various morphometric dimensions and the carapace width (independent variable) of xanthid species (sensu MacLeay, 1838). The respective allometry is also listed. LPL: Major propodus length; A: allometry; LPH: Major propodus height; GL: gonopod length; AW: female abdomen width; JM: juvenile males; AM: adult males; JF: juvenile females; AF: adult females; +: positive allometry; -: negative allometry.

\begin{tabular}{|c|c|c|c|c|c|c|c|c|c|}
\hline Species [Reference] & Demographic category & LPL & $\mathbf{A}$ & LPH & $\mathbf{A}$ & GL & $\mathbf{A}$ & AW & $\mathbf{A}$ \\
\hline Eriphia gonagra (Fabricius, 1781) & JM & 1.05 & + & 0.99 & + & 1.54 & + & & \\
\hline \multirow[t]{3}{*}{ [Góes and Fransozo, 1997] } & $\mathrm{AM}$ & 1.07 & + & 1.01 & 0 & 0.98 & 0 & & \\
\hline & $\mathrm{JF}$ & 1.01 & 0 & 0.98 & & & & 1.47 & + \\
\hline & $\mathrm{AF}$ & 0.75 & 0 & 0.97 & & & & 1.27 & + \\
\hline Panopeus austrobesus (Williams, 1983) & $\mathrm{JM}$ & 1.04 & 0 & 1.09 & + & 2.14 & + & & \\
\hline \multirow[t]{3}{*}{ [Negreiros-Franzoso and Franzoso, 2003] } & $\mathrm{AM}$ & 1.18 & + & 1.25 & 0 & 1.08 & 0 & & \\
\hline & $\mathrm{JF}$ & & & & & & & 1.19 & + \\
\hline & $\mathrm{AF}$ & 1.08 & + & 1.14 & & & & 1.36 & + \\
\hline Eurytium limosum (Say, 1818) & $\mathrm{JM}$ & 1.11 & + & 1.16 & + & 1.17 & + & & \\
\hline \multirow[t]{3}{*}{ [Guimarães and Negreiros-Fransozo, 2002] } & $\mathrm{AM}$ & & & & - & 0.93 & - & & \\
\hline & JF & & & & & & & 1.29 & + \\
\hline & $\mathrm{AF}$ & & & & & & & 1.13 & + \\
\hline Hexapanopeus schmitti (Rathbun, 1930) & $\mathrm{JM}$ & 1.23 & + & 1.40 & - & 0.83 & - & & \\
\hline \multirow[t]{3}{*}{ [Fumis et al., 2007] } & $\mathrm{AM}$ & 0.97 & 0 & 0.85 & + & 1.22 & + & & \\
\hline & JF & 1.00 & 0 & & & & & 1.48 & + \\
\hline & $\mathrm{AF}$ & 1.17 & + & & & & & 1.29 & + \\
\hline Acantholobulus schmitti (Rathbun, 1930) & $\mathrm{JM}$ & 1.11 & + & 1.69 & + & 1.32 & + & & \\
\hline \multirow[t]{3}{*}{ [present study] } & $\mathrm{AM}$ & 1.29 & + & 1.31 & - & 0.61 & - & & \\
\hline & JF & 0.21 & 0 & 0.27 & & & & 0.44 & - \\
\hline & $\mathrm{AF}$ & 1.01 & + & 6.74 & & & & 1.07 & + \\
\hline
\end{tabular}

According to Hartnoll (1974), positive allometry in the period prior to puberty serves to develop the structure to a functional size. During ontogeny, the growth rate of this structure could decrease relative to that of other structures (negative allometry). Species showing such negative allometry can benefit from the resulting increase in reproductive and adaptive potential.

The heterochely recorded in both sexes of $A$. schmitti is remarkable. The most marked case of heterochely was observed in the male crab, in which the major chela (10.67 mm in length and $6.28 \mathrm{~mm}$ in height) was approximately 1.3 and 1.4 times larger, respectively, than the minor chela ( $8.51 \mathrm{~mm}$ in length and $4.46 \mathrm{~mm}$ in height). The sexual dimorphism in the size of the chelae may be related to the more frequent occurrence of agonistic interactions in males than in females and may consequently increase the success of the males in intraspecific agonistic interactions and mate competition (Hartnoll, 1978; Lee and Seed, 1992; Claxton et al., 1994; Negreiros-
Fransozo and Fransozo, 2003). However, heterochely may also be important for feeding or may increase the range of food items that can be obtained. This assumption is based on the observation that the muscles can differ because of the differing form and size of the chelipeds. These differences may function to capture different prey types or food items, as in xanthids and portunids, potentially facilitating predation on prey of different sizes (Abby-Kalio and Warner, 1984).

The predominance of right-handedness in both sexes in A. schmitti appears to be a species characteristic, as previous studies have also reported this tendency (Fumis et al., 2007). Other studies of brachyuran species have shown similar results (Vanini and Gherardi, 1988; Guimarães and Negreiros-Fransozo, 2002; Masunari and Swiech-Ayoub, 2003; Negreiros-Fransozo and Fransozo, 2003), but the meaning of this tendency is still unknown.

The population of $A$. schmitti from the oyster farm studied in Guaratuba Bay became sexually mature earlier 
than a population from the coast of São Paulo state. The lanterns used in oyster farming provide a safe habitat to all the benthic stages of this crab species.

\section{Acknowledgments}

We are grateful to the oyster farmer Mr. Belém for supporting us during the field work, to M.Sc. André Trevisan for the help with the statistical analyzes, to CAPES (Coordination of Development of Higher Education) and to $\mathrm{CNPq}$ (Brazilian Council for Scientific and Technological Development) for scholarships to the first and second authors, respectively. This is Contribution No. 1839 of Zoology Department, Federal University of Paraná.

\section{References}

ABBY-KALIO, NJ. and WARNER, GF., 1984. Effects of two different feeding regimes on the chela closer muscles of the shore crab, Carcinus maenas. Marine Behaviour Physiology, vol. 11, p. 209-218.

ALVES, ES., RODRIGUES, SA. and PEZZUTO, PR., 2005. Estudo do crescimento relativo de Austinixa patagoniensis (Rathbun) (Decapoda, Pinnotheridae) simbionte de Callichirus major (Say) (Decapoda, Callianassidae) no mesolitoral da praia de Balneário Camboriú, Santa Catarina, Brasil. Revista Brasileira de Zoologia, vol. 22, no. 3, p. 784-792.

ARAÚJO, MSLC., NEGROMONTE, AO., BARRETO, AV. and CASTIGLIONI, D., 2012. Sexual maturity of the swimming crab Callinectes danae (Crustacea: Portunidae) at Santa Cruz Channel, a tropical coastal environment. Journal of the Marine Biological Association of the United Kingdom, vol. 92, no. 2, p. 287-293.

BIAGI, R. and MANTELATTO, FL., 2006. Relative growth and sexual maturity of the hermit crab Paguristes erythrops (Anomura, Diogenidae) from South Atlantic. Hydrobiologia, vol. 559, no. 1, p. 247-254.

CASTIGLIONI, D. and COELHO, P., 2011. Determinação da maturidade sexual de Ucides cordatus (Crustacea, Brachyura, Ucididae) em duas áreas de manguezal do litoral sul de Pernambuco, Brasil. Iheringia Série Zoologia, vol. 101, no. 1-2, p. 138-144.

CASTIGLIONI, DS. and NEGREIROS-FRANSOZO, ML. 2004. Comparative analysis of the relative growth of $U c a$ rapax (Smith) (Crustacea, Ocypodidae) from two mangroves in São Paulo, Brazil. Revista Brasileira de Zoologia, vol. 21, no. 1, p. 137-144.

CASTIGLIONI, D., NEGREIROS-FRANSOZO, ML. and MORTARI, RC., 2006. Biologia populacional do caranguejo violinista Uca rapax (Smith, 1870) (Crustacea, Ocypodoidea), proveniente de uma área de manguezal degradado em Paraty, RJ, Brasil. Atlântica, vol. 28, p. 73-86.

CLAXTON, WT., GOVIND, K. and ELNER, RW., 1994. Chela function, morphometric maturity, and the mating embrace in male snow crab, Chionoecetes opilio. Canadian Journal of Fisheries and Aquatic Sciences, vol. 51, p. 11101118.

FELDER, DL. and MARTIN, JW., 2003. Establishment of a new genus for Panopeus bermudensis Benedict \& Rathbun, 1891 and several other xanthoid crabs from the Atlantic and Pacific oceans (Crustacea: Decapoda:
Xanthoidea). Proceedings of the Biological Society Washington, vol. 116, no. 2, p. 438-452.

FERNÁNDEZ-VERGAZ，V., LOPEZ-ABELLAN, LJ. and BALGUERIAS, E., 2000. Morphometric, functional and sexual maturity of the deep-sea red crab Chaceon affinis inhabiting Canary Island waters: chronology of maturation. Marine Ecology Progress Series, vol. 204, p. 169 178.

FINNEY, WC. and ABELE, LG., 1981. Allometric variation and sexual maturity in the obligate coral commensal Trapezia ferruginea Latreille (Decapoda: Xanthidae). Crustaceana, vol. 41, p. 113-130.

FRIGOTTO, SF., 2011. Fauna carcinológica vágil associada às lanternas de ostreicultura na Baía de Guaratuba, PR. Curitiba: Universidade Federal do Paraná. 71 p. Dissertação de Mestrado em Ciências Biológicas - Zoologia.

FUMIS, PB., FRANSOZO, A., BERTINI, G. and BRAGA, AA., 2007. Morphometry of the crab Hexapanopeus schmitti (Decapoda: Xanthoidea) on the northern coast of the state of São Paulo, Brazil. Revista de Biología Tropical, vol. 55, p. 163-170.

GARVEY, JE. and STEIN, RA., 1993. Evaluating how chela size influences the invasion potencial of an introduced crayfish (Orconectes rusticus). The American Midland Naturalist, vol. 129, p. 172-181.

GERHART, SD. and BERT, TM., 2008. Life-history aspects of stone crabs (genus Menippe): size at maturity, growth, and age. Journal of Crustacean Biology, vol. 28, no. 2, p. 252-261.

GÓES, JM. and FRANSOZO, A., 1997. Relative growth of Eriphia gonagra (Fabricius, 1781) (Crustacea, Decapoda, Xanthidae) in Ubatuba, State of São Paulo, Brazil Nauplius, vol. 5, no. 2, p. 85-98.

GUERRERO-OCAMPO, CM., NEGREIROS-FRANSOZO, ML. and COSTA, TM., 1998. Comparação do peso dos quelípodos e crescimento em duas espécies de "Sirís" do gênero Callinectes (Brachyura, Portunidae). Brazilian Archives of Biology and Technology, vol. 41, no. 4, p. 483488.

GUIMARÃES, FJ. and NEGREIROS-FRANSOZO, ML., 2002. Sexual maturity of Eurytium limosum (Say, 1818) from a subtropical mangrove in Brazil. In ESCOBARBRIONES, E. and ALVAREZ, F. (Eds.). Modern approaches to the study of Crustacea. New York: Kluwer; Plenum. p. 157-161.

GRANDJEAN, F.; ROMAIN, D.; AVILA-ZARZA, C.; BRAMARD, M.; SOUTY-GROSSET, C. and MOCQUARD, JP., 1997. Morphometry, sexual dimorphism and size at maturity of the white-clawed crayfish, Austropotamobius pallipes pallipes (Lereboullet) from a wild French population at Deux-Sevres (Decapoda, Astacidea). Crustaceana, vol. 70, p. 31-44.

HARTNOLL, RG., 1974. Variation in growth pattern between some secondary sexual characters in crabs (Decapoda Brachyura). Crustaceana, vol. 27, no. 2, p. 131-136.

HARTNOLL, RG., 1978. The determination of relative growth in Crustacea. Crustaceana, vol. 34, no. 3, p. 281-293.

HARTNOLL, RG., 1982. Growth. In ABELE, LG. (Ed.). The biology of Crustacea. Embriology, morphology and genetics, vol. 2. New York: Academic Press. p. 11-196.

HUBER, ME., 1985. Allometric growth of the carapace in Trapezia (Brachyura, Xanthidae). Journal of Crustacean Biology, vol. 5, no. 1, p. 79-83.

HUXLEY, JS., 1950. Relative growth and form transformation. Proceedings of the Royal Society B: Biological Sciences, vol. 137 , no. 889 , p. $465-469$. 
LEE, SY. and SEED, R., 1992. Ecological implications of cheliped size in crabs: some data from Carcinus maenas and Liocarcinus holsatus. Marine Ecology Progress Series, vol. 84, p. 151-160.

LEME, MHA., 2006. Investimento reprodutivo e produção de ovos em desovas consecutivas do caranguejo Aratus pisonii (H. Milne Edwards) (Crustacea, Brachyura, Grapsoidea). Revista Brasileira de Zoologia, vol. 23, no. 3, p. 727-732.

MARENGHI, F., OZBAY, G., ERBLAND, P. and SNOOKROSSI, K., 2010. A comparison of the habitat value of sub-tidal and floating oyster (Crassostrea virginica) aquaculture gear with a created reef in Delaware's Inland Bays, USA. Aquaculture International, vol. 18, no. 1, p. 69-81.

MARIAPPAN, P., BALASUNDARAM, C. and SCHIMITZ, B., 2000. Decapod crustacean chelipeds: an overview. Journal of Biosciences, vol. 25, no. 3, p. 301-313.

MAROCHI, MZ. and MASUNARI, S., 2011. Os caranguejos Eriphiidae, Menippidae, Panopeidae e Pilumnidae (Crustacea Brachyura) de águas rasas do litoral do Paraná, com chave pictórica de identificação para as espécies. Biota Neotropica, vol. 11, no. 3, p. 21-33.

MASUNARI, S., 2006. Distribuição e abundância dos caranguejos Uca Leach (Crustacea, Decapoda, Ocypodidae). Revista Brasileira de Zoologia, vol. 23, no. 4, p. 901-914.

MASUNARI, S. and DISSENHA, N., 2005. Alometria no crescimento de Uca mordax (Crustacea, Decapoda, Ocypodidae) na Baía de Guaratuba, Paraná, Brasil. Revista Brasileira de Zoologia, vol. 22, no. 4, p. 984-990.

MASUNARI, S., DISSENHA, N. and FALCÃO, RC., 2005. Crescimento relativo e destreza dos quelípodos de $U c a$ maracoani (Latreille) (Crustacea, Decapoda, Ocypodidae) no Baixio Mirim, Baía de Guaratuba, Paraná, Brasil. Revista Brasileira de Zoologia, vol. 22, no. 4, p. 974-983.

MASUNARI, S. and SWIECH-AYOUB, BP., 2003. Crescimento relativo em Uca leptodactyla Rathbun (Crustacea Decapoda Ocypodidae). Revista Brasileira de Zoologia, vol. 20, no. 3, p. 487-491.

MCLAY, CL. and BRINK, AM., 2009. Relative growth and size at sexual maturity in Halicarcinus cookie (Brachyura: Hymenosomatidae): why are some crabs precocious moulters? Journal of the Marine Biological Association of the United Kingdom, vol. 89, no. 4, p. 743-752.

MELO, GAS., 1996. Manual de identificação dos Brachyura (caranguejos e siris) do litoral brasileiro. São Paulo: Plêiade; FAPESP. 604 p.

MILKE, LM. and KENNEDY, VS., 2001. Mud crabs (Xanthidae) in Chesapeake Bay: claw characteristics and predation on epifaunal bivalves. Invertebrate Biology, vol. 120 , no. 1 , p. 67-77.

MUINO, R., FERNANDEZ, L., GONZALEZ-GURRAIARAN, E., FREIRE, J. and VILAR, JA., 1999. Size at maturity of Liocarcinus depurator (Brachyura: Portunidae): a reproductive and morphometric study. Journal of the
Marine Biological Association of the United Kingdom, vol. 79, p. 29-303

NEGREIROS-FRANSOZO, ML. and FRANSOZO, V., 2003. A morphometric study of the mud crab, Panopeus austrobesus Williams, 1983 (Decapoda, Brachyura) from a subtropical mangrove in South America. Crustaceana, vol. 76 , no. 3, p. 281-294

PEZZUTO, PR., 1993. Regrans: a "basic" program for an extensive analysis of relative growth. Atlântica, vol. 15, p. 93-105

PINHEIRO, MAA. and FRANSOZO, A., 1993. Relative growth of the speckled swimming crab Arenaeus cribrarius (Lamarck, 1818) (Brachyura: Portunidae), near Ubatuba, state of São Paulo, Brazil. Crustaceana, vol. 65, p. 377 389.

PINHEIRO, MAA. and TADDEI, FG., 2005. Crescimento do caranguejo de água doce Dilocarcinus pagei Stimpson, 1861 (Crustacea, Brachyura, Trichodactylidae). Revista Brasileira de Zoologia, vol. 22, p. 523-527.

RUESINK, JL., LENIHAN, HS., TRIMBLE, AC., HEIMAN, KW., MICHELI, F., BYERS, JE. and KAY, MC., 2005. Introduction of non-native oysters: ecosystem effects and restoration implications. Annual Review of Ecology and Systematics, vol. 36, p. 643-689.

SANKARANKUTTY, C. and MANNING, RB., 1997. Observations on Hexapanopeus schmitti Rathbun from Brazil (Crustacea: Decapoda: Xanthidae). Proceedings of the Biological Society of Washington, vol. 110, no. 2, p. 249255.

SILLIMAN, BR., LAYMAN, CA., GEYER, K. and ZIEMAN, JC., 2004. Predation by the black-clawed mud crab, Panopeus herbstii, in Mid-Atlantic salt marshes: further evidence for top-down control of marsh grass production. Estuaries, vol. 21, no. 2, p. 188-196.

SOKAL, RR. and ROHLF, FJ., 1979. Biometry. New York: Freeman. $887 \mathrm{p}$.

SWENNEN, C., DUIVEN, P. and SPAANS, AL., 1982. Numerical density and biomass of macrobenthic animals living in the intertidal zone of Surinam, South America. Netherlands Journal of Sea Research, vol. 15, no. 3-4, p. 406418.

TREVISAN, A. and SANTOS, S., 2012. Crescimento de Aegla manuinflata (Decapoda, Anomura, Aeglidae) em ambiente natural. Iheringia, Série Zoologica, vol. 101, p. 336342.

VANNINI, M. and GHERARDI, F., 1988. Studies on the pebble crab, Eriphia smithii MacLeay, 1838 (Xanthoidea Menippidae): patterns of relative growth and population structure. Tropical Zoology, vol. 1, no. 2, p. 203-216.

WELLS, HW., 1961. The fauna of oyster beds, with special reference to the salinity factor. Ecological Monographs, vol. 31, no. 3, p. 239-266.

WILLIAMS, AB. and BOSCHI, EE., 1990. Panopeus margentus, a new crab from the Argentine warm temperate subregion (Decapoda: Xanthidae). Proceedings of the Biological Society of Washington, vol. 103, no. 3, p. 598601 